[計 測自 動制 御 学 会 論文集

Vol.51, No.2, 83/91 (2015)

\title{
接触面を考慮したソフトフィンガ型把持の安定性評価
}

\author{
原 田 研 介*・过徳 生**藤 平 祥 孝***渡 辺 哲 陽**** \\ 宇 都 宗一郎*****·山野辺 夏 樹*·永 田 和 之*·北 垣 高 成*
}

\section{Stability Evaluation of Soft-finger Grasp Considering the Contact Surface}

\author{
Kensuke Harada*, Tokuo Tsuji**, Yoshinori FujihirA***, Tetsuyou Watanabe****, \\ Soichiro Uto ${ }^{* * * * *}$, Natsuki YamanoBe* ${ }^{*}$ Kazuyuki NAGata* ${ }^{*}$ and Kosei KitagakI*
}

\begin{abstract}
This paper discusses the grasp stability under gravity where each finger makes soft-finger contact with an object. By using the intersection of polygon models between a finger and an object, the contact area between a finger and an object is obtained. Then, by assuming the Winkler elastic foundation model, the pressure distribution within the contact area is obtained. By using this pressure distribution, we determine the grasp stability under soft-finger contact. We further consider defining a quality measure of the soft-finger grasp by assuming that, while the gravitational force is applied to an object, the direction of gravity is unknown. To demonstrate the effectiveness of the proposed approach, we show several numerical examples. Finally, we show an experimental results on identification of physical parameters of elastic material attached at the finger surface.
\end{abstract}

Key Words: stable grasp, soft-finger contact, gravity, force closure

\section{1.はじめに}

把持安定性は多指ハンドが対象物を落とさずに把持できる 把持姿勢を評価するための指標として広く用いられている ${ }^{1)}$. 把持安定性は, 把持対象物に加わる 6 次元の力 ・モーメント の集合が原点を含む場合に満足される．このとき，把持は対 象物に対するすべての方向からの外乱に耐えることが保証さ れる。

一方，近年多くの産業用ロボットが生産現場において導入

* 産業技術総合研究所知能システム研究部門 つくば市梅園 1-1-1

** 九州大学大学院システム情報科学研究院 福岡市西区元岡 744

*** 金沢大学大学院自然科学研究科 金沢市角間町

**** 金沢大学大学理工研究域 金沢市角間町

***** 九州大学大学院システム情報科学府 福岡市西区元岡 744

* Intelligent Systems Research Institute, National Institute of Advanced Industrial Science and Technology (AIST), 1-1-1 Umezono, Tsukuba

** Faculty of Information Science and Electrical Engineering, Kyushu University, 744 Motooka, Nishi-ku, Fukuoka

*** Graduate School of Natural Science and Technology, Kanazawa University, Kakumamachi, Kanazawa

**** College of Science and Engineering, Kanazawa University, Kakumamachi, Kanazawa

***** Graduate School of Information Science and Electrical Engineering, Kyushu University, 744 Motooka, Nishiku, Fukuoka

(Received September 23, 2014)

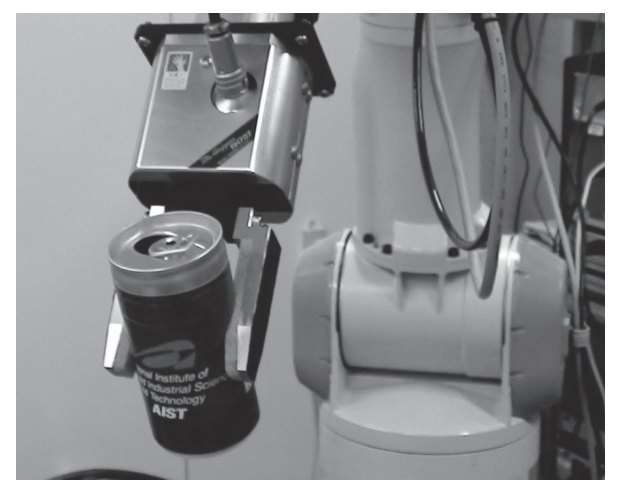

Fig. 1 Grasping a can with soft-finger contact

されているが，多くの産業用ロボットには先端に 2 指のパラ レルグリッパが装備されている。ここで，従来から多くの研 究において用いられてきたように2),3)，指が対象物に 3 次元 の並進力のみを加えることが可能である摩擦あり点接触を仮 定すると，ハンドが対象物を安定に把持するためにはハンド は 3 指を有することが必要である。このため， 2 指グリッパ の指表面には，ゴムなどの柔軟なシートが貼り付けられてい る場合が多い (Fig. 1). 指の表面に柔軟なシートが貼り付け られている場合，指と対象物の接触に伴いシートが変形する ことで，指と対象物が面で接触する。これにより，接触領域 において据じり摩擦が発生することになり，2 指により対象 物の安定な把持を実現することが可能になる。このような指 と対象物の接触形態はソフトフィンガ型接触と呼ばれる。こ こで，ソフトフィンガ型接触においては，㨝じり摩擦の大き 
さは接触領域の大きさや対象物の形状に依存するため, 把持 安定性も接触領域の大きさや対象物の形状に依存する。また, これらは指表面に貼り付けられたシートの弾性係数に依存す るにもかかわらず, 従来の把持安定性に関する研究では, 対 象物の形状やシートの弾性変形に関する効果は考慮されてい なかった。 それに対して, 本研究では指表面に貼り付けられ たシートの柔軟性を考慮することで，指が対象物に接触した 際の接触領域の大きさや対象物の形状の影響を考慮したソフ トフィンガ型接触における把持安定性を議論する.

著者らは, 先行研究 ${ }^{4)} に$ にいてすでにソフトフィンガ型把 持の安定性を議論している. 先行研究 ${ }^{4)}$ では, 入力として接 触点の位置, 各接触点における柔軟シートの最大変形量, 静 止摩擦係数, ならびに柔軟材の弾性係数を与えると, 対象物 が発生可能な力・モーメントの集合を求めるものであった.

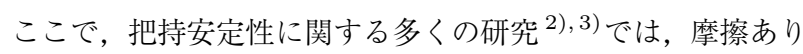
点接触を仮定して，入力として最大変形量の代わりに最大法 線力を仮定するか, あるいは無限の最大法線力が発生できる と仮定して, 対象物に加わる力・モーメントの集合を求めて いる. 最大法線力であれば最大関節トルクにヤコビ行列を掛 けることで求めることができるのに対して, 最大変形量を与 えることは実際問題として困難である．特に，多くの柔軟把 持では複数の接触点で変形量が異なるが, 先行研究では個々 の接触点で適切に最大変形量を与えることはほぼ困難であっ た。それに対して，本論文では多くの従来研究と同様に各接 触点における最大法線力を入力として与えるソフトフィンガ 型把持の安定性判別手法を提案する. この手法では, 指と対 象物が重なる領域を逐次的に増やしながら，そのときの最大 法線力などの物理量を求めるものである. また, 先行研究に おいては, 一つの指リンクが対象物と接触する領域は一つで あったが, 本論文では一つの指リンクは複数の領域で対象物 と接触することが可能である。これにより，ハンドがボルト のネジ山の部分を把持するような場合も扱うことが可能にな る.最後に，本手法を実際に用いるためには静止摩擦係数と 柔軟シートの弾性係数に関する情報が必要である，本論文で は，実験によりこれらの物理パラメータを同定する。

本論文においては，2 章で従来研究を紹介した後に，3 章で は定義を示す. 4 章では接触領域を考慮した把持安定性の定 式化を行なう。また，5章では重力を考慮した把持安定性の 評価指標を示す． 6 章では数值例を示し， 7 章では実験的に 物理パラメー夕を同定する手法を示す. 最後に 8 章において はいくつかのトピックについて議論する.

\section{2. 関連研究}

把持安定性はロボット工学における古典的な問題であり, 現在まで多くの研究が行なわれてきている1),2),5) 13). 把持

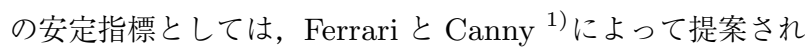
た手法が広く用いられている。この安定指標においては，与 えられた把持姿勢に対して把持対象物に加わる 6 次元の力 · モーメントの集合が原点を中心とする 6 次元の球を含むと把
持は安定と定義され，この球の半径が安定余裕となる.ここ で, 多くの従来研究においては, 指と対象物との接触形態と して摩擦あり点接触が仮定されおり，ソフトフィンガ型接触 を仮定した把持安定性の研究は事例が少ないのが実情である. Howe と Cutkosky ${ }^{14)}$ はソフトフィンガ型接触における力 モーメントのモデルを定式化した. Ciocarlie ${ }^{11)}$, Charusta $ら^{15)}$ や著者ら ${ }^{16)}$ はソフトフィンガ型接触を仮定した把持安 定性について議論している。しかしながら, Ciocarlie ら ${ }^{11)}$ やCharusta ら ${ }^{15)}$ の研究においては接触領域は一定の大きさ の楕円や円を仮定している．また，著者らは対象物のポリゴ ンモデルをクラスタリング16)することで, ハンドとの接触領 域を導き, Winkler Elastic Foundation モデルに基づいて接 触領域の圧力分布を導いた $\left.{ }^{4)}, 17\right)$ 。ここで, この手法において はポリゴンモデルのクラスタリングを用いており，あらかじ め各クラス夕の厚みを指定している ${ }^{4)}$. このため, 各クラス 夕に加わる法線力の最大值をあらかじめ設定することは不可 能であった。また，ポリゴンモデルのクラスタリングを用い るため, 対象物上で一つの指と接触する領域は一つ ${ }^{4), 17) や ~}$ 二つ17)に限定されていいた。 それに対して, 本研究はポリゴ ンモデルにおける領域を定義する手法を新たに提案すること で, 従来研究に存在していた問題点を解消することを目的と する. 本研究では, あらかじめ指が対象物に加える最大法線 力を指定することが可能であり，また一つの指と対象物が複 数の点で接触する場合も取り扱うことが可能である.

また, 弾性変形を伴う接触の研究に関しては, 長い歴史が あり ${ }^{18)}$, たとえばロボットハンドで対象物の弾性変形を利用 した把持や安定性に関しても研究が行なわれている ${ }^{19) ~ 21)}$. ただし，上記述べたような力・モーメントの集合が原点を含 むという意味でのソフトフィンガ型把持の把持安定性 (Grasp Stability)については研究事例が少ない.

\section{3. 定義}

多指のロボットハンドが対象物を把持する姿勢が与えられ ている状況を仮定する。ここで, 対象物と接触する指の表面 は平らであり，指表面に弾性変形するシートが貼り付けられ ている場合を想定する。また, 対象物は剛体で変形しないと 仮定する. $\boldsymbol{f}_{i}, \boldsymbol{\tau}_{i}(i=1, \ldots, m)$ は対象物の第 $i$ 接触点にお いて対象物が指から受ける力, モーメントであり, また, $\tau_{n i}$, $\boldsymbol{\tau}_{t i}$ は，それぞれ $\boldsymbol{\tau}_{i}$ の接触点における法線方向成分と接線方 向成分を表わす.ソフトフィンガ型接触では, 各接触点にお いて指は対象物に 3 次元の力と法線まわりのモーメントを加 えることができる。つまり, 対象物が指から受ける合力・合 モーメント $\boldsymbol{\omega}$ は次式により定義される.

$$
\boldsymbol{\omega}=\sum_{i=1}^{m} \boldsymbol{G}_{i}\left[\begin{array}{c}
\boldsymbol{f}_{i} \\
\tau_{n i}
\end{array}\right]
$$

ここで,

$$
\boldsymbol{G}_{i}=\left[\begin{array}{cc}
\boldsymbol{I} & 0 \\
\gamma\left[\boldsymbol{p}_{i} \times\right] & \gamma \boldsymbol{n}_{i}
\end{array}\right]
$$


であり, $\boldsymbol{p}_{i}, \boldsymbol{n}_{i}$ は，それぞれ接触点の位置と法線べクトルで ある.また, $\boldsymbol{I}$ は単位行列, $\left[\boldsymbol{p}_{i} \times\right]$ は外積と等価な歪対称行 列を表わす。ここで，本研究においては対象物と指は領域を もって接触するため, $\boldsymbol{p}_{i}$ の選択には任意性が生じる，本論文 では, $\boldsymbol{p}_{i}$ として接線まわりのモーメントが 0 になる点を用い, この点の具体的な定式化は次章で示す．また，このために上 式では接線まわりのモーメントが陽な形としては含まれてい ない.また， $\gamma$ はモーメントの值をスケーリングするために 導入する定数 ${ }^{22)}$ であるが, 本論文の数值例では $\gamma$ はすべて一 定の值とし, 対象物のスケール不变性 ${ }^{22)}$ は特に考慮していな い.また，対象物座標系の原点の位置としては対象物の重心 を仮定した。

本研究では与えられた把持姿勢に対して，把持の安定性を 判定する。このとき，指に貼り付けられた柔軟なシートの変 形を近似的に表わすため, 対象物が剛体のシートにめり込ん だ状況を仮定する。この仮定の下で，指と対象物の双方に対 してポリゴンモデルを仮定する.

\section{4. ソフトフィンガ型接触}

本章では，指と対象物の接触領域を定義し，その接触領域 における圧力分布に基づいた把持安定性を定式化する.

\section{1 圧力分布}

$\mu$ を対象物と指の接触における摩擦係数とする. ソフトフィ ンガ型接触において，第 $i$ 接触点における力とモーメントが 存在する範囲は次式により定義される ${ }^{14)}$.

$$
\boldsymbol{f}_{t i}^{t} \boldsymbol{f}_{t i}+\frac{\tau_{n i}^{2}}{e_{n i}^{2}} \leq \mu^{2} f_{n i}^{2}
$$

(2) 式は多指ハンドがソフトフィンガ型接触により対象物を把 持する場合に，各接触点において満足しなくてはならない式 である。ここで, $e_{n i}$ は Eccentricity パラメー夕11)であり， 対象物の形状，接触領域の大きさ，あるいは指に貼り付けら れた柔軟シートの弾性係数に依存して変化する。本章では, Eccentricity パラメータを定式化する．手法の概略を Fig. 2 に示す．指に貼り付けられたシートの厚みを $h$ とする．与え られた把持姿勢において, 対象物と指がソフトフィンガ型接触 をすることを近似的に表わすため, 対象物がシートへめり込ん でいる状況を考える。ささらに，このめり込み量に基づいて接 触領域における圧力分布を導出する。最終的に, Eccentricity パラメータは接触領域において分布する圧力や摩擦力を積分 することで得られる。

本論文では，Winkler elastic foundation model ${ }^{18)}$ を用い て圧力分布を導出する。ここで, Winkler elastic foundation model は, せん断応力を無視した弾性変形のモデルであり, このモデルに基づいて圧力分布を求めることが可能である.

Fig. 3 に示すように，シート表面に定義された座標系におい て, $z$ 座標が指の法線方向を表わす場合を考える. 対象物が シートにめり込んでいる領域において $u_{i}(x, y)$ をシート表 面に定義された座標系から見た指表面上の点 $(x, y, 0)$ から対

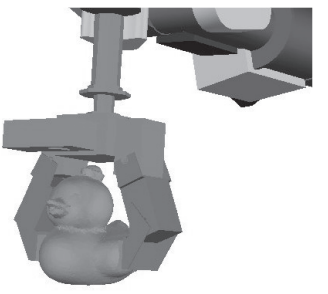

(a) Two-Fingered Grasp of an Object

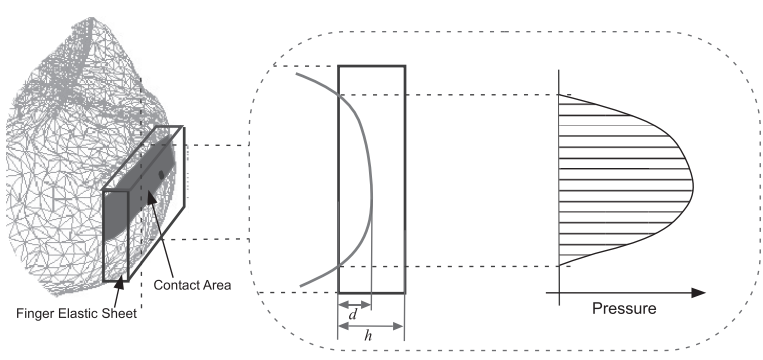

(b) Definition of Penetration Depth and Pressure Distribution

Fig. 2 Calculation of pressure distribution

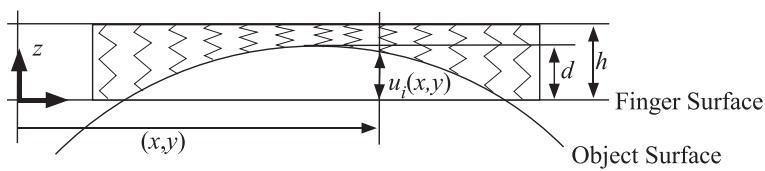

Fig. 3 Definition of deformation within the contact area

象物表面への $z$ 方向の距離と定義する。 また，接触領域内に おける $u_{i}(x, y)$ の最大值を $d$ と定義する.

めり込み量と法線方向の弾性変位量が等価であると仮定す ると，圧力は以下により定義される.

$$
p_{i}(x, y)=\frac{K}{h} u_{i}(x, y)
$$

ここで，Kは Elastic moduleを表わす．（3）式より，接触点 における力やモーメントは, 対象物がシートにめり込んでい る領域におけるめり込み量を積分することで以下のように求 めることができる.

$$
\begin{aligned}
f_{\max , n i} & =\int_{S} \frac{K}{h} u_{i}(x, y) d S \\
f_{\max , t i} & =\int_{S} \mu \frac{K}{h} u_{i}(x, y) d S \\
\tau_{\max , n i} & =\int_{S} \sqrt{x^{2}+y^{2}} \mu \frac{K}{h} u_{i}(x, y) d S
\end{aligned}
$$

ここで， $\int_{S}$ は接触領域における面積積分を表わす. 上式によ り, Ececntricity パラメータ $e_{n i}$ は次式により求めることが できる。

$$
e_{n i}=\frac{\tau_{\max , n i}}{f_{\max , t i}}
$$

また, 前章では接触点 $\boldsymbol{p}_{i}$ を接線まわりのモーメントが 0 に なる点として定義したが，具体的にはつぎのように定式化す ることができる。

$$
{ }^{c} x_{i}=\frac{\int_{S} x \frac{K}{h} u_{i}(x, y) d S}{f_{\max , n i}}
$$




$$
\begin{aligned}
{ }^{c} y_{i} & =\frac{\int_{S} y \frac{K}{h} u_{i}(x, y) d S}{f_{\max , n i}} \\
\boldsymbol{p}_{i} & =\boldsymbol{p}_{c i}+\boldsymbol{R}_{c i}\left[\begin{array}{c}
{ }^{c} x_{i} \\
{ }^{c} y_{i} \\
0
\end{array}\right]
\end{aligned}
$$

ここで, $\boldsymbol{p}_{c i}, \boldsymbol{R}_{c i}$ は対象物座標系から見たシート表面に定義 された座標系の位置, 姿勢を表わす。

\section{2 めり込み量の決定}

前節では，指に貼り付けられたシートの対象物に対する最 大めり込み量 $d$ が与えられた場合に，接触領域における最大 法線力や Eccentricity パラメータを計算する手法を示した. ここで，把持安定性を判定する場合，最大めり込み量として どのような值を設定したらいいかを決める問題は自明ではな い，そこで，本節では最大めり込み量を与えるのではなく，最 大法線力を与えることを考え，これにより Eccentricity パラ メータを計算する手法を示す。

本手法では, めり达み量の最大值 $d$ を 0 から $\Delta d$ ずつ増や し, その時点での法線力を (4) 式により計算する. そして, 法 線力が，上限值 $\bar{f}_{\text {max }}$ を超えない範囲で $\bar{f}_{\text {max }}$ に一番近づいた 時点での Eccentricity パラメータを出力する．このアルゴリ ズムは以下のようにまとめることができる.

\section{Algorithm 1 (Calculation of Eccentricity Parame-}

\section{ter)}

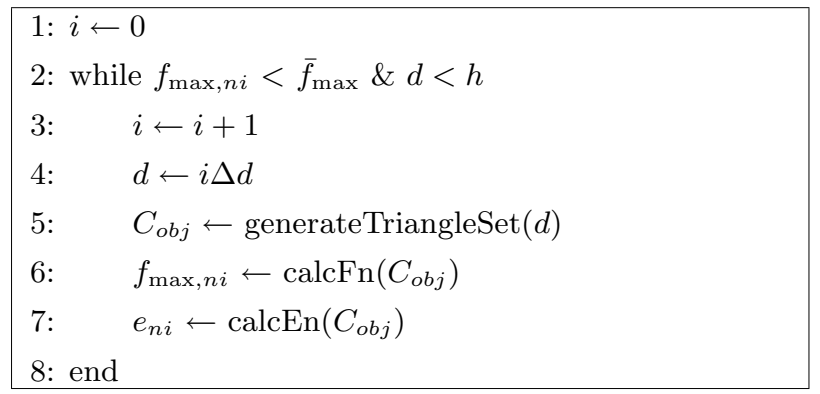

ここで, 関数 generateTriangleSet $(d)$ は対象物のシートに対 するめり込み量が与えられたとき, 対象物のポリゴンモデル を構成する三角形のうち，シートの内部に含まれる集合を求 める関数である. Fig. 4 に示すとおり, 対象物のポリゴンモ デルを構成する各三角形がシートの内部に含まれるかどうか をチェックする。ここで, 三角形のうち，一部だけがシート の内部に含まれる場合は，含まれる部分で三角形を再構成す る.このようにして構成される三角形の集合を $C_{o b j}$ と定義 する。つぎに，関数 $\operatorname{calcFn}\left(C_{o b j}\right), \operatorname{calcEn}\left(C_{o b j}\right)$ は，それぞ れ (4), (7) 式を計算する関数である.ただし, 本研究では対 象物のポリゴンモデルを仮定しており，(4), (5), (6) 式に含 まれる面積積分は対象物のポリゴンモデルにおける三角形の 各面における值を足し合わせることにより，離散的に求める こととする

\section{5. 重力下での把持安定指標}

つぎに, (2) 式を各接触点で満足するような Grasp Wrench

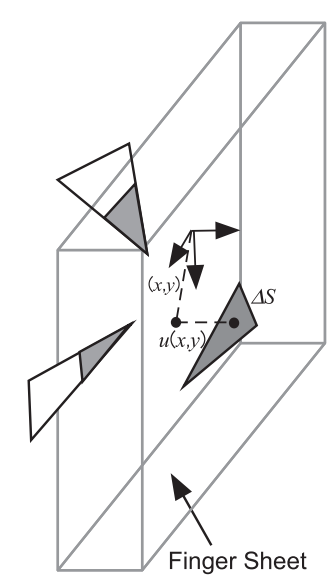

Fig. 4 Derivation of contact area based on the clustering object polygon model

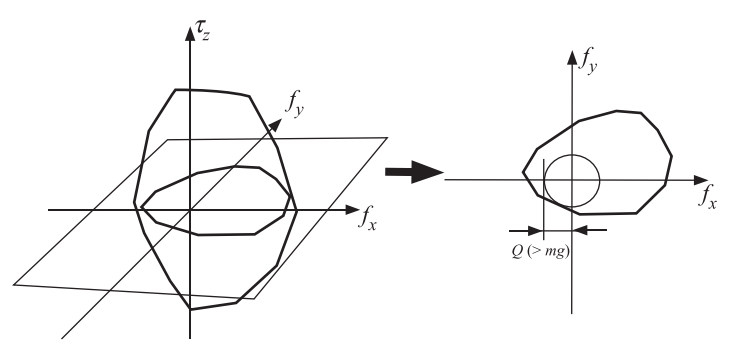

Fig. 5 Proposed method, taking the gravitational force into consideration

Set (GWS) を定義し，重力の影響を考慮した把持安定性の判 定手法を説明する。ここで，本章で導入する重力の影響を考 慮する手法自体は先行研究 ${ }^{4)}$ で述べたものであり，また定式 化の手法は異なるが文献 22) において比較検討されているよ うに, 従来研究の範疇に含まれるものである.

(2) 式は各接触点における力とモーメントが存在する集合 を定義しているため，これを $\left(f_{i}^{T}, \tau_{n i}\right)^{T} \in S F C$ として記述 する。なお， $S F C$ は Soft Finger Contact の略である。こ こで, GWS を定義する方法として Minkowski 和を用いるも のと, Unit Wrench の合併集合を用いるものが存在する ${ }^{1)}$. 本研究で提案する手法は, この両方に対して定義することが できるが，特に Minkowski 和を用いると GWS は以下のよ うに定義できる ${ }^{12)}$.

$$
\begin{aligned}
W_{L^{\infty}}^{c h}= & \left\{\sum_{i=0}^{m} \boldsymbol{G}_{i}\left[\begin{array}{c}
\boldsymbol{f}_{i} \\
\tau_{n i}
\end{array}\right] \mid\left(\boldsymbol{f}_{i}^{T}, \tau_{n i}\right)^{T} \in S F C,\right. \\
& \left.f_{n i} \leq \bar{f}_{\max }\right\}
\end{aligned}
$$

つぎに，把持の安定指標を定義する．Ferrari ら ${ }^{1)}$ の手法を 適用し, 対象物に重力が働くが, 重力の方向が未知の場合を 考える. 手法の概要を Fig. 5 に示す。ここで, Fig. 5 は 2 次 元の並進力と 1 次元の回転モーメントの場合を記しているが, 同様な議論は 3 次元の並進力と 3 次元の回転モーメントの場 合にも当てはまる. $\boldsymbol{\omega}=\left(\boldsymbol{\omega}_{f}^{T}, \boldsymbol{\omega}_{\tau}^{T}\right)^{T}$ を対象物に作用する 3 次元の並進力と 3 次元の回転モーメントから構成される 6 次 元のレンチと仮定する。一般性を損なうことなく，対象物座 
標系の原点が対象物の重心と一致する場合を考える。

Fig. 5 において左側の図は (11) 式で定義される GWS の領 域を表わす。つぎの積集合を考える。

$$
W_{i n t}=W_{L^{\infty}}^{c h} \cap W_{\tau},
$$

ここで, $W_{\tau}=\left\{\boldsymbol{\omega} \mid \boldsymbol{\omega}_{\tau}=\mathbf{0}\right\}$ である. この積集合を, 本研究で は GWS intersection と呼ぶことにする，GWS intersection において, 中心が原点にあり, 半径が $m g$ の球を考える.こ こで, $m$ は対象物の質量である. 本研究では, GWS intersectionがこの球を含むなら, 把持安定性が満足されると定義 する。この場合，GWS intersectionにおける原点から境界 までの最短距離が安定指標 $Q$ となり, $Q>m g$ の場合に把持 安定が満足される。このとき，どのような方向から重力がは たらく場合でも把持を維持することが可能である.

ここで，把持安定性を判定する場合，摩擦円錐を多面錐近似 する手法が用いられている1),11),12)。文献 11)においては, ソフトフィンガ型接触に対して (2) 式で定義される領域を凸 多面体で近似している. 本研究で提案する手法に対しても, (2) 式で定義される領域を凸多面体で近似する手法を用いる ことが可能である。それに対して，著者らは摩擦円錐を複数 の楕円体で近似することで Force Closure の判定を行なう手 法を提案した ${ }^{13)}$ 。この手法では摩擦円錐を粗い近似で表現す るが, Force Closure の判定にかかる計算量が非常に小さく なることが特徴である。そこで，本研究においても，摩擦円 錐を複数の楕円体で近似する手法を用いることとした。

\section{6. 数 值 例}

提案する手法の有効性を示すため, 数值計算の結果を示す. 数值例に用いた対象物はアヒルの玩具とテレビのリモコンで ある.これらのポリゴンモデルのポリゴン数を Table 1 に 示す.

まず，アヒルの玩具の頭部を 2 指ハンドで把持した場合の 計算結果を Table 2 や Fig. 6 に示す。この計算では, 最 大法線力 $\bar{f}_{\text {max }}$ に応じて把持安定性がどのように変化する かを調べる。この数值例においては， $\mu=0.8, K=4 \mathrm{MPa}$ $\Delta d=0.01 \mathrm{~mm}, h=5 \mathrm{~mm}$ とした. なお，この Elastic module $K$ の值は，ほぼゴムの值に相当する．Fig. 6 では，接触 領域を赤色で描いている. 表は図からわかるとおり， $\bar{f}_{\text {max }}$ を 小さくすると，それに応じて Eccentricity パラメータ $e_{n i} や$ 接触面積が小さくなり，把持の安定指標 $Q$ も小さくなる．対 象物の重量は $0.2 \mathrm{~kg}$ であるので, 安定指標 $Q$ は $1.96 \mathrm{~N}$ より 小さいと不安定となる。 $\bar{f}_{\text {max }}=30 \mathrm{~N}$ ，ならびに $20 \mathrm{~N}$ では安 定であるが， $\bar{f}_{\text {max }}=10 \mathrm{~N}$ では不安定となる結果が得られた. なお，CPUのクロック周波数が $3.33 \mathrm{GHz}$ の PC を用いて計

Table 1 Polygon models used in numerical examples

\begin{tabular}{|l|c|}
\hline Object Name & Number of polygons \\
\hline Bolt & 1282 \\
\hline Duck Toy & 127162 \\
\hline
\end{tabular}

算したところ，把持安定性の計算に $0.11 \mathrm{~s}$ から $0.148 \mathrm{~s}$ 程度 の時間を要した。この計算時間にうち, 一つの接触領域を計 算するのに要した時間は $0.030 \mathrm{~s}$ から $0.053 \mathrm{~s}$ 程度である。

つぎに，アヒルの頭部に対して，嘴と後頭部がハンドと接 触するように把持した場合の結果を Table 3 と Fig. 7 に示 す。この数值例においては, 同じ $\bar{f}_{\text {max }}$ を仮定しても, 対象 物の形状に応じて $d$ の值が変化することを示す。この数值例 においては， $K=1 \mathrm{MPa}$ としたが，それ以外のパラメータに 関しては先ほどの例と同じに設定した，表と図からわかると おり，両方の接触領域において同様に $\bar{f}_{\text {max }}=20 \mathrm{~N}$ と設定し ているにもかかわらず，嘴の部分のほうが後頭部と比較して $d$ の值が大きくなっていることがわかる．なお，この数值例 において，把持安定性の計算に要した時間は $0.273 \mathrm{~s}$ であり，

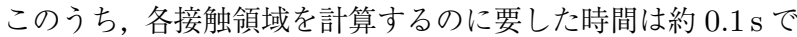
ある.

さらに, 2 指ハンドがボルトを把持する例の計算結果を Table 4 と Fig. 8 に示す．この数值例では，一つの指が複数の 接触領域を同時にもつ場合の計算結果を記す。眓からわかる ように，接触領域に含まれるボルトのネジ山が指と複数の領 域で接触しており，この場合でも把持の安定性を計算できて いることがわかる。

\section{7. 同 定 実 験}

本論文を実機に適用する場合，ハンドの指表面に貼り付け られた柔軟シートの物理パラメータを同定する必要がある。 本章では，特に弾性係数と静止摩擦係数を同定した結果を述 ベる.

Fig. 9 に実験システムの模式図を示す。二つの自動ステー ジを用いて，指をアクリル板に押し付けながらアクリル板の 接線方向と法線方向の荷重を加える. 接線方向の力（摩擦力） はフォースゲージで, 法線方向の力は自作した平行平板構造 のロードセルで計測を行なう。接線方向の自動ステージはア クリル板を押す方向に一定速度で動作するように制御をする. 法線方向の自動ステージは法線荷重が設定した荷重になるよ うに制御を行なう。

Fig. 10 に示すように，指には円筒形のシリコンを取り付 けた。また，把持対象物を模擬するため，アクリル板の上に は蒲鉾型をしたアクリルを取り付けた。

まず，アクリル板に蒲鉾型のアクリルをつけない状態で，ア クリル板の法線方向のみに力を加えることで，シリコンの弾 性係数を測定した。この結果を Fig. 11 に示す. 図に示すよ うに，このシリコンの弾性係数は $4.47 \mathrm{~N} / \mathrm{mm}$ であり，これ より Elastic Moduleは $K=0.406 \mathrm{MPa}$ と得られた。

つぎに，摩擦係数の測定を行なった。本実験では，まず法 線荷重を設定した上で, 法線方向にスライダを動かし, 法線荷 重が設定した值になったところで，法線方向のスライダを停 止する．つぎに，接線方向のステージを $1 \mathrm{~mm} / \mathrm{s}$ の速度で動 作させる。このとき, 接触面で滑りが発生すると, 増加して いた接線荷重が一時的に減少し，その後，増減を繰り返すス 
Table 2 Calculation results for grasping duck toy 1

\begin{tabular}{|l|c|c|c|c|c|c|c|}
\hline $\bar{f}_{\text {max }}[\mathrm{N}]$ & $Q[\mathrm{~N}]$ & $d[\mathrm{~mm}](\mathrm{L})$ & $d[\mathrm{~mm}](\mathrm{R})$ & $e_{n}(\mathrm{~L})$ & $e_{n}(\mathrm{R})$ & Contact Area $\left[\mathrm{m}^{2}\right](\mathrm{L})$ & Contact Area $\left[\mathrm{m}^{2}\right](\mathrm{R})$ \\
\hline 30 & 6.48 & 0.52 & 0.6 & $3.27 \mathrm{e}-3$ & $3.28 \mathrm{e}-3$ & $8.62 \mathrm{e}-5$ & $9.0 \mathrm{e}-5$ \\
\hline 20 & 3.12 & 0.45 & 0.51 & $2.98 \mathrm{e}-3$ & $2.89 \mathrm{e}-3$ & $7.61 \mathrm{e}-5$ & $7.55 \mathrm{e}-5$ \\
\hline 10 & 0.24 & 0.32 & 0.35 & $2.52 \mathrm{e}-3$ & $2.52 \mathrm{e}-3$ & $5.55 \mathrm{e}-5$ & $5.08 \mathrm{e}-5$ \\
\hline
\end{tabular}

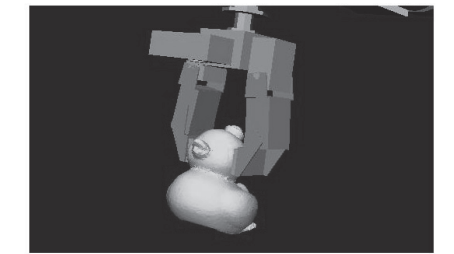

(a) Overview of grasping pose

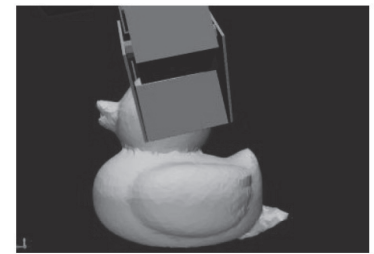

(b) View from Left

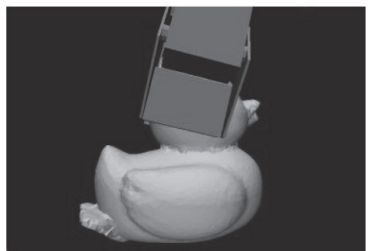

(c) View from Right

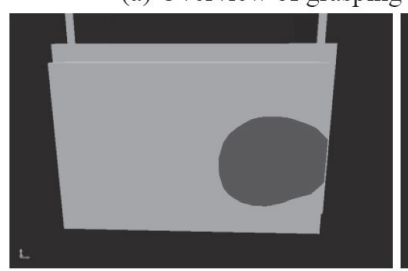

(d) Contact Area(Left, $\left.f_{\max }=30[\mathrm{~N}]\right)$

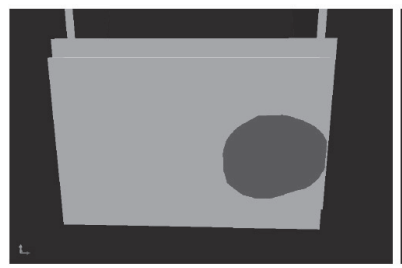

(f) Contact Area(Left, $\left.f_{\max }=20[\mathrm{~N}]\right)$

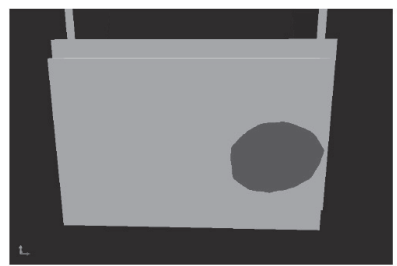

(h) Contact Area(Left, $\left.f_{\max }=10[\mathrm{~N}]\right)$
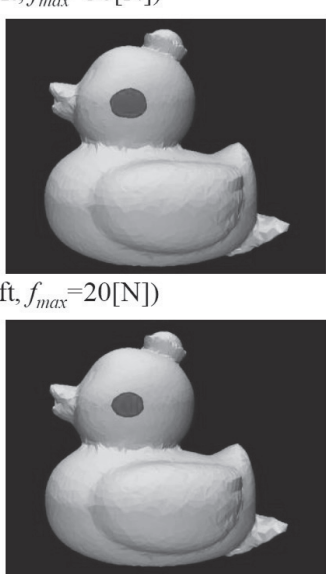

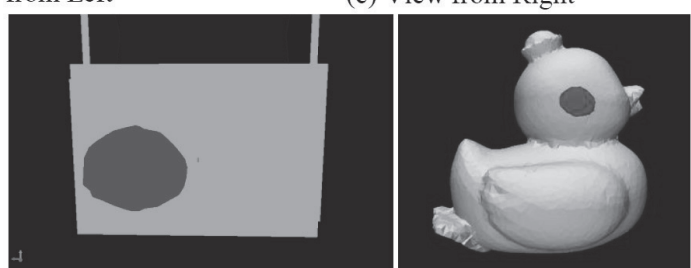

(e) Contact Area(Right, $f_{\max }=30[\mathrm{~N}]$ )
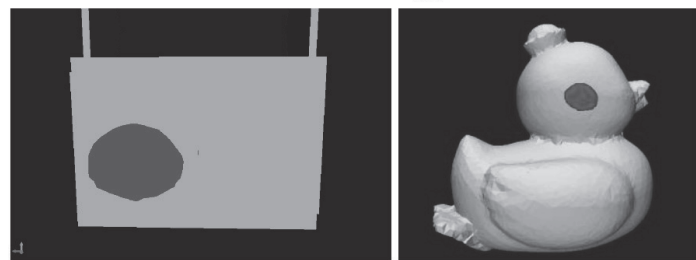

(g) Contact Area(Right, $f_{\max }=20[\mathrm{~N}]$ )
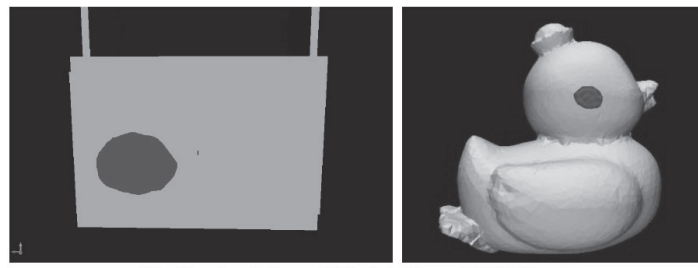

(i) Contact Area(Right, $\left.f_{\max }=10[\mathrm{~N}]\right)$

Fig. 6 Example grasp of a duck toy 1: where (h) and (i) show unstable cases

Table 3 Calculation results for grasping duck toy 2

\begin{tabular}{|l|c|c|c|c|c|c|c|}
\hline $\bar{f}_{\max }[\mathrm{N}]$ & $Q[\mathrm{~N}]$ & $d[\mathrm{~mm}](\mathrm{L})$ & $d[\mathrm{~mm}](\mathrm{R})$ & $e_{n}(\mathrm{~L})$ & $e_{n}(\mathrm{R})$ & Contact Area $\left[\mathrm{m}^{2}\right](\mathrm{L})$ & Contact Area $\left[\mathrm{m}^{2}\right](\mathrm{R})$ \\
\hline 20 & 4.01 & 2.20 & 1.02 & $4.18 \mathrm{e}-3$ & $3.81 \mathrm{e}-3$ & $6.90 \mathrm{e}-5$ & $1.22 \mathrm{e}-4$ \\
\hline
\end{tabular}

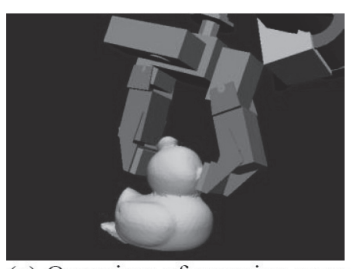

(a) Overview of grasping pose

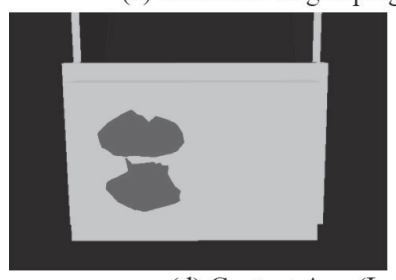

(d) Contact Area(Left, $\left.f_{\max }=20[\mathrm{~N}]\right)$

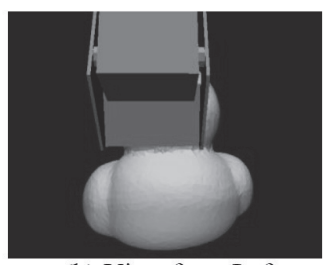

(b) View from Left

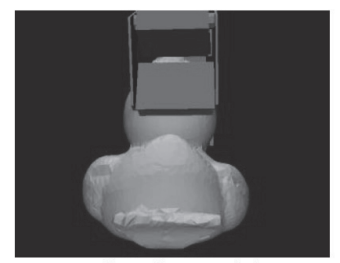

(c) View from Right
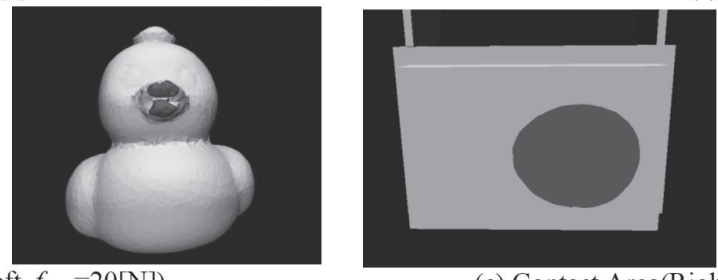

(e) Contact Area(Right, $\left.f_{\text {mor }}=20[\mathrm{~N}]\right)$

Fig. 7 Example grasp of a duck toy 2: where penetration depth is different between right and left 
Table 4 Calculation results for grasping a bolt

\begin{tabular}{|l|c|c|c|c|c|}
\hline $\bar{f}_{\max }[\mathrm{N}]$ & $Q[\mathrm{~N}]$ & $e_{n}(\mathrm{~L})$ & $e_{n}(\mathrm{R})$ & Contact Area $\left[\mathrm{m}^{2}\right](\mathrm{L})$ & Contact Area $\left[\mathrm{m}^{2}\right](\mathrm{R})$ \\
\hline 20 & 6.71 & $8.04 \mathrm{e}-3$ & $4.53 \mathrm{e}-3$ & $1.89 \mathrm{e}-5$ & $2.05 \mathrm{e}-4$ \\
\hline
\end{tabular}

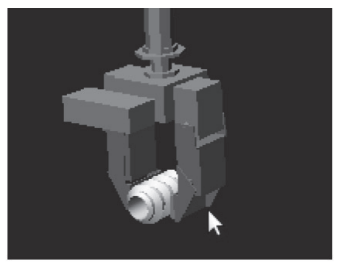

(a) Overview of grasping pose

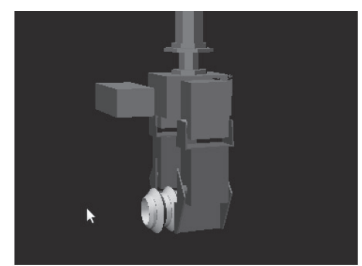

(b) View from Left

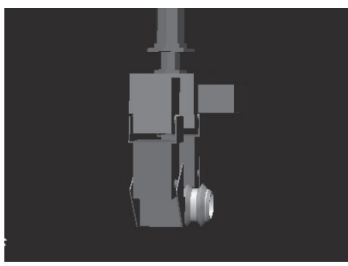

(c) View from Right

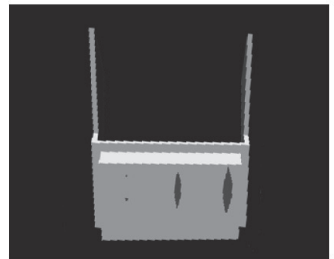

(d) Contact Area(Left, $\left.f_{\max }=20[\mathrm{~N}]\right)$
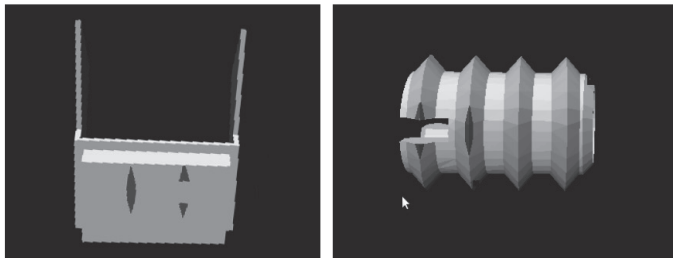

(e) Contact Area(Right, $\left.f_{\max }=20[\mathrm{~N}]\right)$

Fig. 8 Example grasp of a bolt where we can judge the grasp stability for multiple isolated contact areas

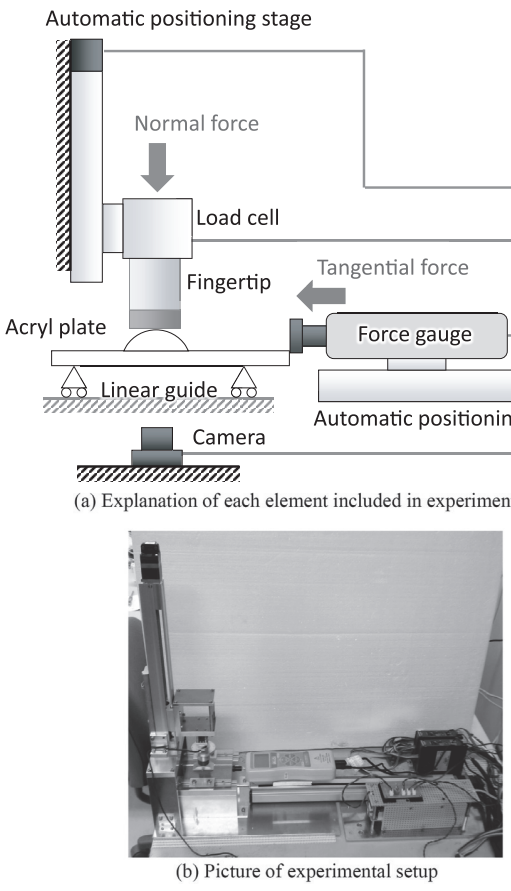

Fig. 9 Experimental setup

ティックスリップ現象が見られる。この現象が見え始めた時 点における接線荷重を記録する。結果を Fig. 12 に丸い点で 示す。なお，この図には比較として蒲鉾型の対象物をアクリ ル板に取り付けない場合の結果も四角い点で描いている。こ こで，蒲鉾型の対象物を取り付けたほうが非線形が強い結果 が得られている。この結果については，次章において，もう 一度議論する。

\section{8. 議論}

本論文で提案している接触領域を計算する手法は，対象物
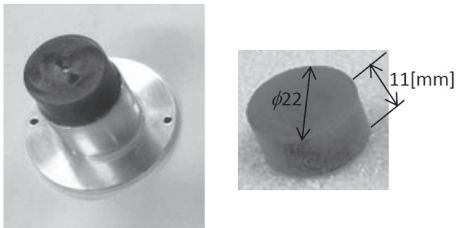

(a) Finger and elastic element

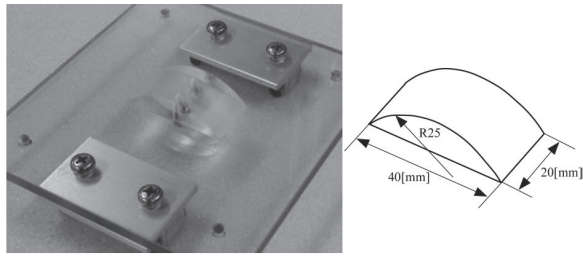

(b) Object and its dimension

Fig. 10 Object and finger used in experiment

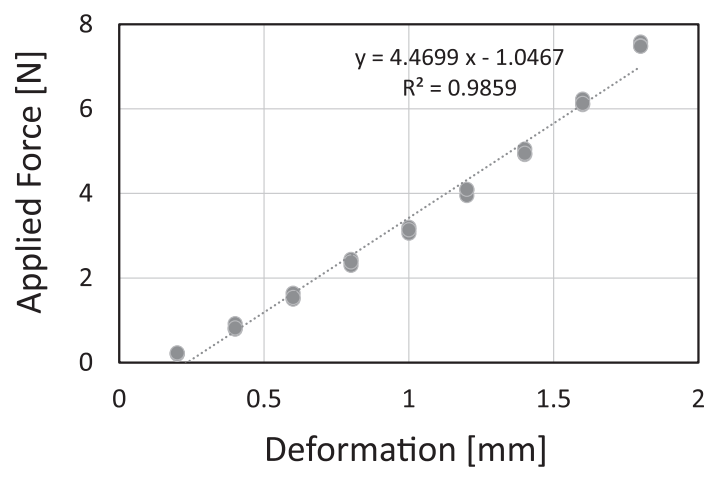

Fig. 11 Calculation of elastic coefficient

のポリゴンが十分細かく，かつ，接触領域におけるせん断応 力の影響が十分に小さい場合に正確になる。ここで, せん断 応力の影響が大きくなると, 本研究で導いた接触領域のうち, 端の部分は実際には接触しないことになり，実際の接触領域 


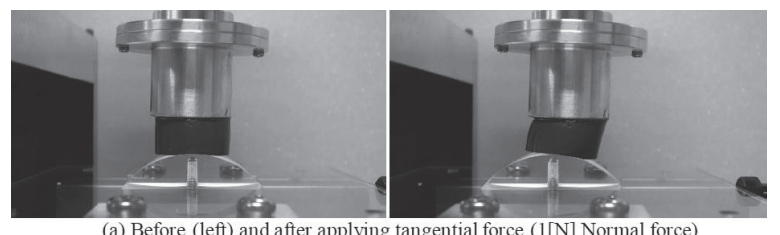

(a) Before (left) and after applying tangential force (1[N] Normal force)

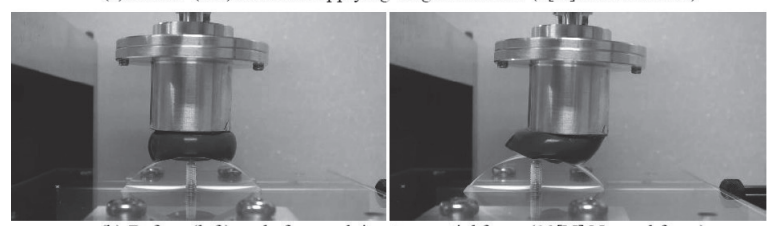

(b) Before (left) and after applying tangential force (10[N] Normal force)

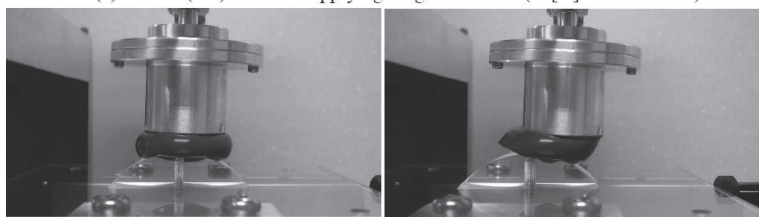

(c) Before (left) and after applying tangential force (20[N] Normal force)

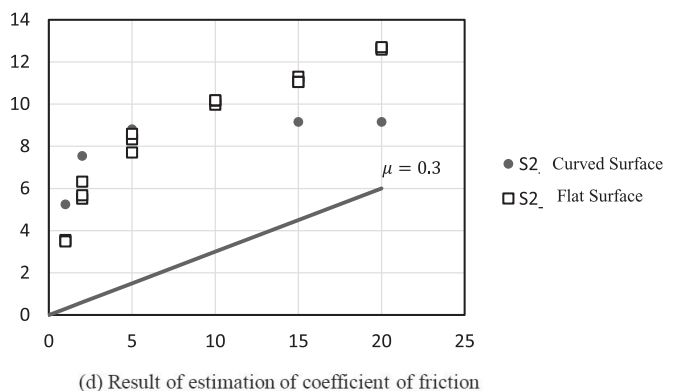

Fig. 12 Calculation of friction coefficient

は本研究で算出される接触領域よりも小さくなることが想定 される，この場合，本研究で提案する手法により算出される 把持安定性は，実際の場合よりも安定になることが想定され る。従来より把持安定性を判定する場合，近似された摩擦円 錐を実際の摩擦円錐よりも小さく設定することで，把持安定 性を保守的に見積もることが行なわれてきた。それに対して， 本手法では，把持をより安定に見積もることになる，せん断 応力の影響を考慮した把持安定性の評価は, 今後の研究課題 である。

また，本論文では平板の形状をした指表面に貼り付けられ た柔軟シートに剛体の対象物が接触する場合を仮定している が，実際の接触では接触面が指表面とは必ずしも平行ではな くなり, 複雑な摩擦力が生じる。そこで定式化の段階では, 簡 単のために剛体の平板指に柔軟な対象物が接触すると仮定し て, 摩擦力を求めていることに相当する. Fig. 12 に扔ける静 止摩擦係数の同定において強い非線形性が現れたのは，この 仮定に起因していると考えられる。ここで，静止摩擦係数の 不確実性は安定な把持と判定されたにもかかわらず，実際に ハンドが対象物を把持する際に対象物を落とすことの原因と なる可能性がある，そこで, 把持安定性の研究においては, 静 止摩擦係数を実際の值よりも小さく見積もることにより, 安 定把持の十分条件を導出することが行なわれてきた ${ }^{23)}$. たと えば，本研究の実験結果を使い法線力が最大 $20 \mathrm{~N}$ 程度だと仮
定すると, Fig. 12 に実線で示した静止摩擦係数 $\mu=0.3 く ら$ いの值であれば十分性が確保されることになる.

\section{9.おわりに}

本論文ではソフトフィンガ型接触を仮定し，把持安定性を判 定する手法を提案した．対象物と指のポリゴンモデルの交わ りにより接触領域を定義した。 また，Winkler elastic foundation model を用いることで，接触領域の圧力分布を導出す ることで，把持安定性を求める手法を提案した．さらに，重 力下での把持安定性の安定指標について議論した。提案する 手法の有効性を数值例により確認すると共に，実験的に物理 パラメータを同定する手法について議論した。

現在，本手法は著者らが開発を行なっている把持計画手法 に組み込んで，2 指ハンドによる把持姿勢を導出する際に用い ている．実際のロボットハンドによる把持実験において，提 案する手法がどの程度有効に機能しているかを定量的に吟味 することは今後の課題である。

\section{参 考 文 献}

1) C. Ferrari and J. Canny: Planning Optimal Grasps, Proc. of IEEE Int. Conf. on Robotics and Automation, 2290/2295 (1992)

2) A. Bicchi and V. Kumar: Robotic Grasping and Contact: A Review, Proc. of IEEE Int. Conf. on Robotics and Automation, 348/353 (2000)

3) B. Siciliano and O. Khatib (Eds.): Handbook of Robotics, Springer (2008)

4) K. Harada, T. Tsuji, S. Uto, N. Yamanobe, K. Nagata and K. Kitagaki: Stability of Soft-Finger Grasp under Gravity, Proc. of IEEE Int. Conf. on Robotics and Automation, $883 / 888(2014)$

5) V. Nguyen: Constructing force closure grasps, Int. J. Robot. Res., 7-3, 3/16 (1988)

6) J. Ponce, D. Stam and B. Faverjon: On Computing Twofinger Force-closure Grasps of Curved 2D Objects, Int. J. Robot. Res., 12-3, 263/273 (1993)

7) B. Mishra and N. Silver: Some discussion of static gripping and its stability, IEEE Trans Systems, Man and Cybernetics, 19-4, 783/796 (1989)

8) G.F. Liu and Z.X. Li: Real-time Grasping Force Optimization for Multifingered Manipulation: Theory and Experiments, IEEE/ASME Trans Mechatronics, 9-1, 65/77 (2004)

9) N. Niparnan and A. Sudsang: Positive Span of Force and Torque Components of Three-Fingered Three-Dimensional Force-Closure Grasps, Proc. of IEEE Int. Conf. on Robotics and Automation, 4701/4706 (2007)

10) C. Borst, M. Fischer and G. Hirzinger: A fast and robust grasp planner for arbitrary 3D objects, Proc. of IEEE Int. Conf. on Robotics and Automation, 3, 1890/1896 (1999)

11) M. Ciocarlie, C. Lackner and P.K. Allen: Soft Finger Model with Adaptive Contact Geometry for Grasping and Manipulation Tasks, Proc. of World HAPTICS (2007)

12) Y. Zheng: An Efficient Algorithm for a Grasp Quality Measure, IEEE Trans. on Robotics, 29-2, 579/585 (2013)

13) T. Tsuji, K. Harada and K. Kaneko: Easy and Fast Evaluation of Grasp Stability by using Ellipsoidal Approximation of Friction Cone, Proc. of IEEE/RSJ Int. Conf. on Intelligent Robots and Systems, 1830/1837 (2009) 
14) R.D. Howe and M.R. Cutkosky: Practical Force-Motion Models for Sliding Manipulation, Int. J. Robotics Research, 15-6, 557/572 (1996)

15) K. Charusta, R. Krug, D. Dimitrov and B. Iliev: Independent Contact Regions Based on a Patch Contact Model, Proc. of IEEE Int. Conf. on Robotics and Automation, $4162 / 4169$ (2012)

16) K. Harada, T. Tsuji, K. Nagata, N. Yamanobe, K. Maruyama, A. Nakamura and Y. Kawai: Grasp Planning for Parallel Grippers with Flexibility on its Grasping Surface, Proc. of IEEE Int. Conf. on Robotics and Biomimetics, 1540/1546 (2011)

17）宇都，辻，原田，倉爪，長谷川：応力分布の放物面近似に基 づく把持安定性の評価, 日本ロボット学会学術講演会予稿集, 3G1-07 (2013)

18) K.L. Johnson: Contact Mechanics, Cambridge University Press (1985)

19) C.-H.D. Tsai, I. Kao, N. Sakamoto, M. Higashimori and M. Kaneko: Applying Viscoelastic Contact Modeling to Grasping Task: An Experimental Case Study, Proc. of IEEE/RSJ Int. Conf. on Intelligent Robots and Systems, 1790/1795 (2008)

20) K. Tahara, S. Arimoto and M. Yoshida: Dynamic Object Manipulation Using a Virtual Frame by a Triple Softfingered Robotic Hand, Proc. IEEE Int. Conf. on Robotics and Automation, 4322/4327 (2010)

21) T. Inoue and S. Hirai: Parallel-distributed model in three-dimensional soft-fingered grasping and manipulation, Proc. IEEE Int. Conf. on Robotics and Automation, 2092/2097 (2009)

22) C. Borst, M. Fischer and G. Hirzinger: Grasp Planning: How to Choose a Suitable Task Wrench Space, Proc. of IEEE Int. Conf. on Robotics and Automation, 319/325 (2004)

23) K. Harada and M. Kaneko: A Sufficient Condition for Manipulation of Envelope Family, IEEE Trans. on Robotics and Automation, 18-4, 597/607 (2002)

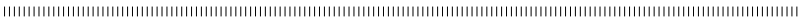

$$
\text { [著 者 紹 介] }
$$

\section{原 田 研 介（正会員）}

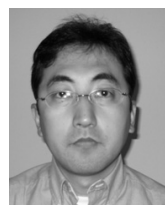

1997 年京都大学大学院工学研究科博士後期課 程修了．同年広島大学工学部助手．2002 年産業技 術総合研究所知能システム研究部門研究員, 2005 年から 1 年間 Stanford 大客員研究員, 2013 年知 能システム研究部門タスクビジョン研究グループ 長，現在に至る。ロボットハンドによる把持・操 り，ロボットの動作計画，ヒューマノイドロボッ 卜などに関する研究に従事. 博士 (工学). IEEE, 日本ロボット学会, 日本機械学会, システム制御 情報学会の会員.

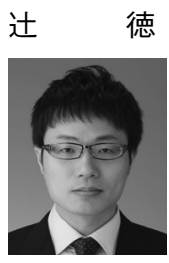

生

2005 年九州大学大学院システム情報科学府知能 システム学専攻博士課程修了. 同年広島大学大学 院工学研究科, COE 研究員. 2008 年産業技術総 合研究所知能システム研究部門, 産総研特別研究 員. 2011 年九州大学大学院システム情報科学府知 能システム学専攻助教, 現在に至る. 多指ハンド, 画像処理, コンピュータグラフィクスの研究に従 事. 博士 (工学). 日本ロボット学会, 電子情報通 信学会，日本機械学会の会員。

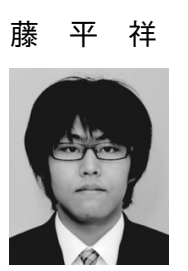

孝（学生会員）

2012 年金沢大学大学院自然科学研究科博士前期 課程修了, 現在博士後期課程在学中. 脳腫瘍摘出 手術用マニピュレータ, 柔軟把持の研究に従事.

\section{渡 辺 哲 陽（正会員）}

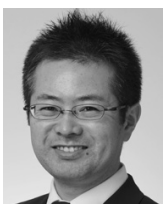

2003 年京都大学大学院工学研究科博士後期課 程修了. 同年山口大学工学部助手. 2006 年講師. 2007 年金沢大学大学院自然科学研究科講師. 2011 年金沢大学理工学研究域准教授，現在に至る。口 ボットハンド，ロボット技術の医療応用，微細操 作システム開発などの研究に従事. 日本生体医工 学会, IEEE, 日本ロボット学会, 日本機械学会の 会員.

\section{宇 都 宗一郎}

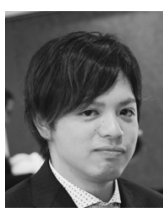

2014 年九州大学大学院システム情報科学府知能 システム学専攻修士課程修了. 在学中は多指ハン ドによる安定把持の研究に従事.

\section{山野辺 夏 樹}

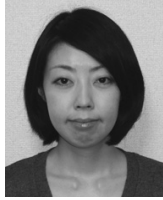

2002 年京都大学工学部物理工学科卒業. 2007 年東京大学大学院工学系研究科精密機械工学専攻 博士課程修了. 2007 年産業技術総合研究所知能 ステム研究部門研究員, 現在に至る. 技能教示, 把 持動作計画，リハビリテーションロボットに関す る研究に従事. 博士 (工学). IEEE, 日本機械学 会, 精密工学会の会員.

\section{永田和之(正会員)}

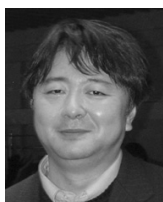

1986 年東北大学工学部精密工学科卒業. 同年, 通産省工業技術院東北工業技術試験所入所. 91 年 電子技術総合研究所. 現在，産業技術総合研究所. ロボットハンドの研究に従事. 博士 (工学). 日本 機械学会, 日本ロボット学会の会員.

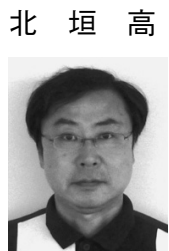

1989 年東北大学大学院工学研究科博士課程修 了．同年通産省工業技術院電子技術総合研究所入 所. 現在，（独）産業技術総合研究所主任研究員. 博士 (工学). 日本機械学会, 日本ロボット学会の 会員. 